\title{
Production of a High Gel Strength Whey Protein Concentrate from Cheese Whey
}

\author{
P. D. Veith and E. C. Reynolds \\ School of Dental Science, \\ The University of Melbourne, \\ Victoria 3000 , Australia
}

\section{ABSTRACT}

In order to develop a process for the production of a whey protein concentrate (WPC) with high gel strength and water-holding capacity from cheese whey, we analyzed 10 commercially available WPC with different functional properties. Protein composition and modification were analyzed using electrophoresis, HPLC, and mass spectrometry. The analyses of the WPC revealed that the factors closely associated with gel strength and water-holding capacity were solubility and composition of the protein and the ionic environment. To maintain whey protein solubility, it is necessary to minimize heat exposure of the whey during pretreatment and processing. The presence of the caseinomacropeptide (CMP) in the WPC was found to be detrimental to gel strength and water-holding capacity. All of the commercial WPC that produced high-strength gels exhibited ionic compositions that were consistent with acidic processing to remove divalent cations with subsequent neutralization with sodium hydroxide. We have shown that ultrafiltration/diafiltration of cheese whey, adjusted to $\mathrm{pH} 2.5$, through a membrane with a nominal molecular weight cut-off of 30,000 at $15^{\circ} \mathrm{C}$ substantially reduced the level of CMP, lactose, and minerals in the whey with retention of the whey proteins. The resulting WPC formed from this process was suitable for the inclusion of sodium polyphosphate to produce superior functional properties in terms of gelation and waterholding capacity.

(Key words: whey protein concentrate, cheese whey, gel strength, caseinomacropeptide)

Abbreviation key: $\mathbf{C M P}=$ caseinomacropeptide, $\mathbf{D F}=$ diafiltration, DTT = dithiothreitol, MALDI-MS = matrix-assisted laser desorption ionization mass spectrometry, $\mathbf{M W C O}=$ molecular weight cut-off, TFA = trifluoroacetic acid, $\mathbf{W P C}=$ whey protein concentrate.

Received May 14, 2003

Accepted October 10, 2003

Corresponding author: E. C. Reynolds; e-mail e.reynolds@unimelb. edu.au.

\section{INTRODUCTION}

Whey protein concentrates (WPC) are value-added dairy products used as food ingredients with specific functional properties (Morr and Foegeding, 1990). The functional properties that are of interest to food manufacturers are gelation, water binding, emulsification, foaming, and heat stability as well as properties related to taste and texture (Mangino, 1984). The production of WPC in North America, Western Europe, and the Pacific Rim is currently 155,000 ton/yr with an approximate value AUD $\$ 1.01$ billion. A particular function of WPC desired by many food manufacturers for bakery, confectionery, structured meat, and seafood applications is the production of a high-strength gel with good water-holding capacity (Mei, et al., 1996). High gel strength WPC currently on the market are limited and are usually produced from acid wheys obtained after casein precipitation. The WPC produced from cheese (sweet) whey are of variable quality (Morr, 1992). However, with the large volume of whey produced from cheese manufacture, a major challenge for the dairy industry is the production of a high gel strength and water-holding WPC from cheese whey.

To develop a process for the production of a high gel strength WPC from cheese whey, we analyzed 10 commercially available WPC with different functional properties. Because gel strength of a WPC has been associated with many factors including $\mathrm{pH}$, ionic strength, protein concentration, and composition, these were determined for all 10 WPC (Mulvihill and Kinsella, 1987; Mangino, 1992; Aguilera, 1995; Rojas et al., 1997). From the results obtained from these analyses, we developed a procedure, which involved $\mathrm{UF}$ and diafiltration (DF) of cheese whey at $\mathrm{pH} 2.5$ with a 30,000 molecular weight cut-off (MWCO) membrane at $15^{\circ} \mathrm{C}$ to remove minerals, lactose, and caseinomacropeptide (CMP), producing WPC that exhibited a superior gel strength and water-holding capacity.

\section{MATERIALS AND METHODS}

\section{WPC Samples}

Samples of WPC were obtained from a variety of European, North American, New Zealand, and Aus- 


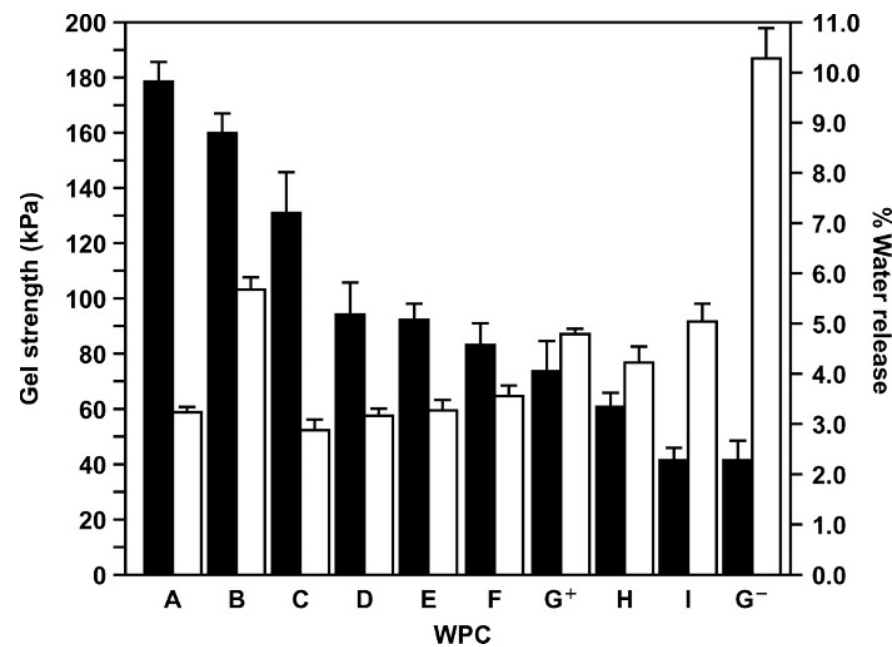

Figure 1. Gel strength ( $\square)$ and water release $(\square)$ of each whey protein concentrate (WPC). The WPC was reconstituted to $15 \% \mathrm{wt} /$ vol $(\mathrm{pH} 7.0)$ and cooked at $75^{\circ} \mathrm{C}$ for $70 \mathrm{~min}$. Cooled gel cylinders were tested for gel strength by recording the force-deformation curve produced when a rod of 3-mm diameter was pushed through the sample until failure. The gel strength was taken as the force at failure divided by the cross-sectional area of the rod. The gel strength presented is the mean measurement from at least 7 gel cylinders. Water release was measured by compressing the gel between absorbent paper. The percentage water release was calculated as the weight of lost water divided by the initial gel weight and is presented as the mean of at least 3 measurements. Error bars represent one standard deviation from the mean. The WPC are labeled A to I. Product $G$ was a cheese whey WPC that was produced with $\left(\mathrm{G}^{+}\right)$and without $\left(\mathrm{G}^{-}\right)$the addition of $3 \% \mathrm{wt} / \mathrm{wt}$ sodium polyphosphate.

tralasian companies and were designated WPC-A through I.

\section{Gelation Procedure}

Solutions of WPC were prepared at $15 \% \mathrm{wt} / \mathrm{vol}$ at room temperature, adjusted to $\mathrm{pH} 7.0$ with $\mathrm{NaOH}$ or $\mathrm{HCl}$, degassed for 5 to 10 min at a water pump, poured into $2-\times 15$-mL screw-capped plastic tubes, and placed in a $75^{\circ} \mathrm{C}$ water bath for $70 \mathrm{~min}$. Gels were cooled for 30 min in $20^{\circ} \mathrm{C}$ water.

\section{Gel Strength Assay}

Gel strength was assessed by a penetration method (Tang et al., 1994) using an Instron universal testing machine (model 5544) fitted with a $1000 \mathrm{~N}$ load cell. Cooled gels were cut into $15-\mathrm{mm}$ lengths one tube at a time immediately prior to testing. A rod with a 3$\mathrm{mm}$ diameter fixed at one end to the load cell was pushed through the sample at a rate of $10 \mathrm{~mm} / \mathrm{min}$ until failure (penetration) was achieved. The load and displacement were simultaneously recorded.

\section{Water-Holding Capacity Assay}

Cooled gels were cut into four 10-mm lengths one tube at a time immediately prior to testing. These slices were placed in a sandwich consisting of (from inside to outside) gel slices arranged in a rectangle, wire mesh, doubly folded tissue paper, and plastic plates and were compressed under $1 \mathrm{~kg}$ for $10 \mathrm{~min}$. The percentage water release was calculated from the difference in weight of the gel slice immediately before and after compression.

\section{WPC Solubility}

Whey protein solubility was determined by preparing WPC solutions at $0.5 \mathrm{mg} / \mathrm{mL}$ in deionized water with $\mathrm{pH}$ adjustment to 7.0. The solution was mixed for $1 \mathrm{~min}$ and then centrifuged at 11,600 $\times \mathrm{g}$ for $30 \mathrm{~min}$. The 280-nm absorbance was measured immediately before and after centrifugation. The percentage 280$\mathrm{nm}$ absorbance recovered was used as an indication of protein solubility. The Bradford protein assay (Biorad) was used for the determination of protein concentration.

\section{Chemical Analyses}

Elements were analyzed using either atomic absorption spectrophotometry or colorimetry (Adamson and Reynolds, 1995). Orthophosphate was measured before and after hydrolysis in $1 M \mathrm{HCl}$ at $100^{\circ} \mathrm{C}$ to provide the level of polyphosphate. Chlorine determinations were performed by Dairy Technical Services (Melbourne, Australia)

\section{One- and Two-Dimensional Electrophoresis}

One-dimensional SDS-PAGE was conducted according to the basic method of Laemmli (1970). Briefly, SDS gels were cast and run using the mini-Protean II system (Biorad) and contained a $12.5 \%$ resolving gel and a $4 \%$ stacking gel. The gels were electrophoresed at $100 \mathrm{~V}$ through the stacking gel and at $160 \mathrm{~V}$ through the resolving gel until the tracking dye reached the bottom of the gel. The gels were stained in $0.1 \%$ Coomassie Brilliant Blue R-250 and destained until acceptable contrast was obtained. Low molecular weight standards from Amersham Biosciences were run in parallel.

For 2-D gel electrophoresis, samples containing 2 $\mathrm{mg}$ of WPC were prepared by diluting a WPC solution $(100 \mathrm{mg} / \mathrm{mL})$ into a sample solution containing $8 \mathrm{M}$ urea, 2\% CHAPS, $10 \mathrm{mM}$ dithiothreitol (DTT), $50 \mathrm{mg} /$ $\mathrm{L}$ bromophenol blue, and 2\% Pharmalytes ( $\mathrm{pH} 4$ to 7 ) (Amersham Biosciences). Immobiline Dry Strips ( $\mathrm{pH}$ 


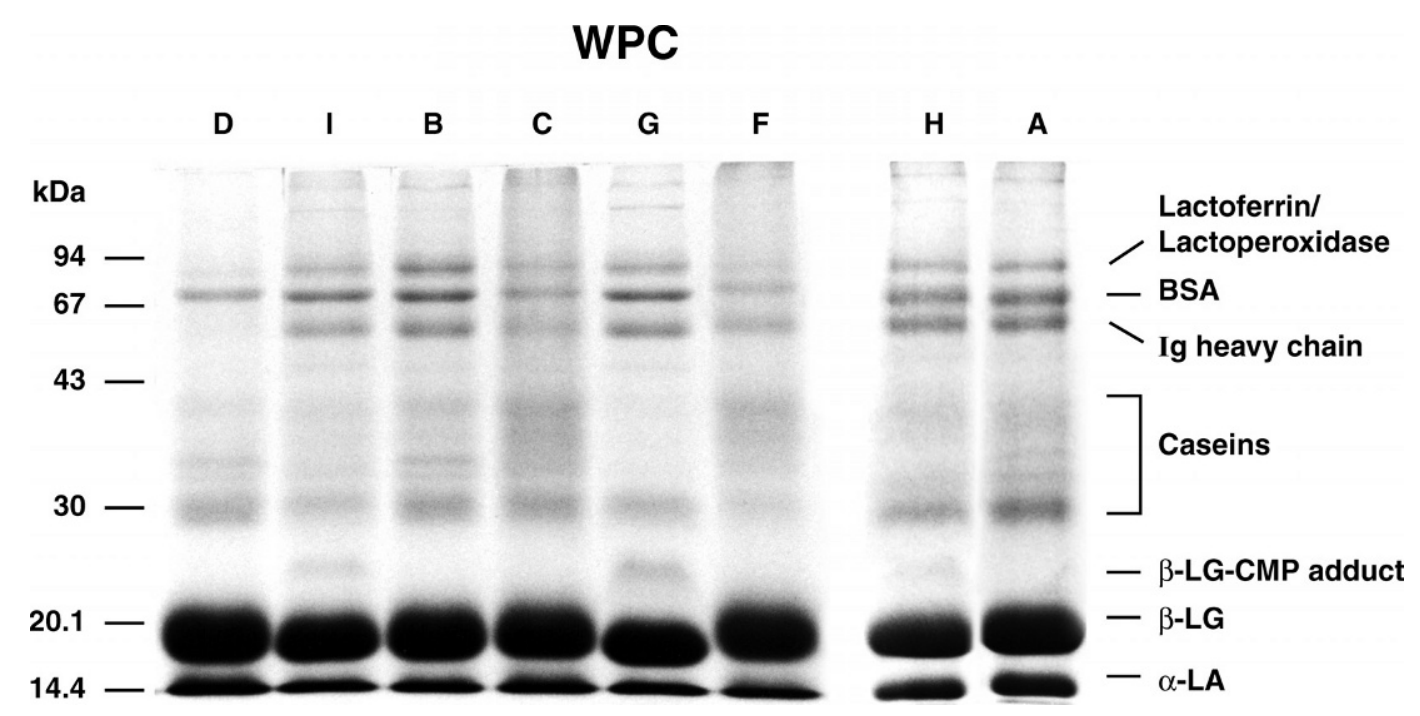

Figure 2. SDS-PAGE of whey protein concentrate (WPC). The WPC was reconstituted to $10 \mathrm{mg} / \mathrm{mL}$ in $\mathrm{H}_{2} \mathrm{O}$ before further reconstitution in Laemmli sample buffer and $2 \% \mathrm{vol} / \mathrm{vol} 2$-mercapto-ethanol. Ten microliters of each sample containing $50 \mu \mathrm{g}$ of WPC were boiled for 5 min prior to SDS-PAGE. CMP = Caseinomacropeptide.

4 to $7 ; 18 \mathrm{~cm}$ ) (Amersham Biosciences) were rehydrated in sample solution (minus the bromophenol blue) for $6 \mathrm{~h}$ or overnight in a sealed 15 -mL test tube. After rehydration, strips were briefly blotted and placed in the grooves of the Immobiline dry strip tray, and $100 \mathrm{uL}$ of sample were loaded at the cathodic end as per instruction manual (Amersham Biosciences). isoelectric focusing settings were $300 \mathrm{~V}, 4 \mathrm{~h} ; 1900 \mathrm{~V}$, $5 \mathrm{~h}$; and $3500 \mathrm{~V}, 30$ to $60 \mathrm{~h}$. Strips were then equilibrated for $20 \mathrm{~min}$ in a solution containing $30 \% \mathrm{wt} / \mathrm{vol}$ glycerol, $6 \mathrm{M}$ urea, $2 \%$ SDS, $50 \mathrm{mg} / \mathrm{mL}$ bromophenol blue, $50 \mathrm{mM}$ Tris- $\mathrm{HCl}$ ( $\mathrm{pH} 6.8$ ), and $10 \mathrm{mM}$ DTT. Strips were then blotted and placed onto the top of a large vertical slab gel, $0.75-\mathrm{mm}$ thick containing $13 \%$ acrylamide, $10 \mathrm{mM}$ DTT, $0.1 \%$ SDS, and $375 \mathrm{mM}$ Tris-HCl ( $\mathrm{pH}$ 8.8). Electrophoresis was conducted at $20 \mathrm{~mA} / \mathrm{gel}$ at $15^{\circ} \mathrm{C}$ until the tracking dye had reached the bottom of the gel. Gels were stained with Coomassie Brilliant Blue R250.

\section{Mass Spectrometry}

Matrix-assisted laser desorption ionization mass spectrometry (MALDI-MS) was performed using a Voyager $\mathrm{DE}^{\mathrm{TM}}$ instrument in linear mode (Applied Biosystems). Whey protein concentrate was prepared in $30 \%$ acetonitrile, $0.1 \%$ trifluoroacetic acid (TFA), and saturated matrix. The matrix employed was $3,5 \mathrm{di}-$ methoxy-4 hydroxy cinnamic acid. The pre-programmed method for myoglobin was used for the analysis.

\section{Gel Filtration HPLC}

Gel filtration was performed on progel TSK columns for HPLC (TOSOHAAS, Japan). The system comprised an SWXL guard column, a G3000SWXL column (30 $\mathrm{cm})$, and a G3000SW column $(30 \mathrm{~cm})$ connected in series, and in that order, to an Applied Biosystems HPLC system. For quantitative analysis of the constituent WPC proteins, sample and running buffer were $30 \%$ acetonitrile/ $0.1 \%$ TFA. Samples were injected into the system using a $20-\mu \mathrm{L}$ injection loop. Detection was at $215 \mathrm{~nm}$, and the flow rate was $1 \mathrm{~mL} / \mathrm{min}$. Under these conditions, $\alpha$-LA, $\beta$-LG, and CMP were baselineresolved. The level of each component was determined by peak integration and reference to a standard. When the aggregation state of the WPC proteins was of interest, only one column was required, and samples were chromatographed in $50 \mathrm{mM}$ sodium phosphate buffer (pH 7.0) with $150 \mathrm{mM} \mathrm{NaCl}$. All samples for use in either system were centrifuged at $10,000 \times g$ to remove insoluble material.

\section{Process Trial}

Pasteurized cheese whey that was used to produce WPC-G was used for the process trial. The trial involved UF and DF performed using a Sartacon Mini system from Sartorius. Single polysulfone UF modules with a filtration area of $0.1 \mathrm{~m}^{2}$ were used with an MWCO of 30,000. The whey was pumped through the system at $15^{\circ} \mathrm{C}$ using a peristaltic pump working at a pressure between 1 and 2 Bar. After $\mathrm{pH}$ adjustment 
to 2.5 with $\mathrm{HCl}$, the whey was concentrated 15 -fold and then diafiltered with $5 \mathrm{vol}$ of deionized water. The $\mathrm{pH}$ was then adjusted to 7.4 with $\mathrm{NaOH}$, and DF continued with $0.7 \mathrm{vol}$ of deionized water to remove excess $\mathrm{Na}$. Finally, the retentate was concentrated to about $20 \%$ TS and freeze-dried.

\section{RESULTS}

\section{Analysis of WPC Samples}

The 10 commercially available WPC were analyzed for gel strength and water-holding capacity (Figure. 1). The gel strengths varied 4 -fold, from $40 \mathrm{kPa}$ to 180 $\mathrm{kPa}$ of force required to penetrate the gels. Only two products (WPC-A and WPC-B) had a strength $>140$ $\mathrm{kPa}$. The gel strength parameter was chosen to order the WPC, which were subsequently labeled A through I (Figure 1). Product G was a cheese WPC that was obtained with $\left(\mathrm{G}^{+}\right)$and without $\left(\mathrm{G}^{-}\right)$the addition of $3 \%$ wt/wt sodium polyphosphate. Unlike high gel strength, good water-holding capacity was common; one-half the WPC samples only lost between 2.9 and $3.6 \%$ of their water under the test conditions (Figure 1). The WPC-A sample was the best product, producing a gel strength of $180 \pm 20 \mathrm{kPa}$ and a water release of only $3.3 \pm 0.1 \% \mathrm{wt} / \mathrm{wt}$.

The bulk composition of the WPC (comprising protein, fat, lactose, ash, and moisture) was very similar, and the small differences noted were not associated with either gel strength or water retention (data not shown). The protein content ranged from 73 to $79 \%$ wt/wt. The solubility, aggregation state, and chemical modification of the WPC proteins were also examined using gel filtration HPLC, 1-D and 2-D electrophoresis, and MALDI-MS. The SDS-PAGE protein profile is shown in Figure 2 with protein assignments for $\beta$ LG, $\alpha$-LA, BSA, and CMP confirmed by N-terminal sequencing; the remaining proteins were assigned by comparison with previously published results. The WPC were found to contain similar levels of the main whey proteins $\beta$-LG and $\alpha$-LA. However, a difference was noted with the 3 low gel strength WPC $(\mathrm{G}, \mathrm{H}$, and I) in that they all contained a band at $24 \mathrm{kDa}$ (Figure 2 ). The $24-\mathrm{kDa}$ band was subjected to N-terminal sequence analysis, which revealed that the band contained CMP and $\beta$-LG in equimolar quantities suggesting a covalent 1:1 adduct. The other difference that was noted in the SDS-PAGE analysis was that the level of lactoferrin/lactoperoxidase and Ig heavy chain were low in some WPC samples.

Gel filtration HPLC analysis of the WPC samples enabled baseline resolution of $\beta$-LG from $\alpha$-LA and CMP and, hence, their quantitation (Figure 3). Caseinomacropeptide was either very low or not detectable in

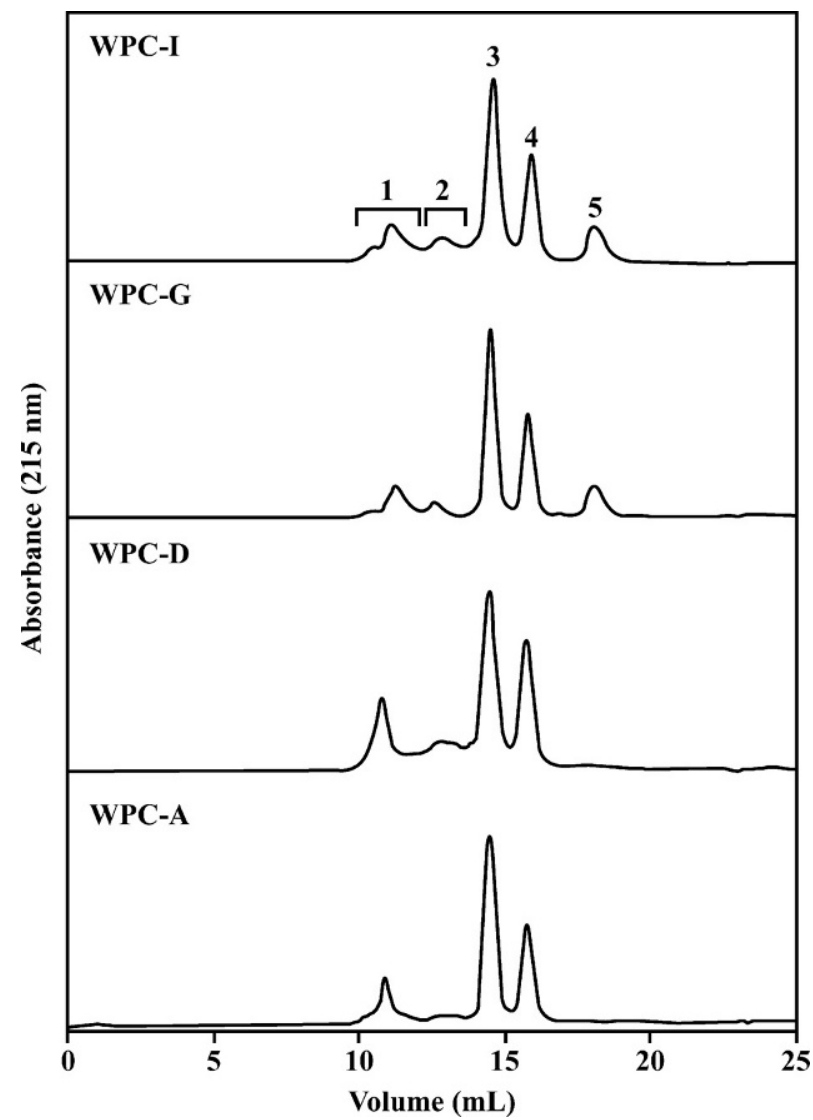

Figure 3. HPLC gel filtration of whey protein concentrate (WPC) samples. At $10 \mathrm{mg} / \mathrm{mL}$ of water, WPC were diluted 10 -fold into running buffer $\left(0.1 \%\right.$ trifluoroacetic acid, $30 \%$ acetonitrile, $\left.70 \% \mathrm{H}_{2} \mathrm{O}\right)$ and centrifuged at $11,000 \times g$. Twenty microliters of supernatant were injected into the system comprising 2 pro-gel TSK columns joined in series with a total volume of $\sim 27 \mathrm{~mL}$. Detection was at $215 \mathrm{~nm}$, and the flow rate was $1 \mathrm{~mL} / \mathrm{min}$. 1 = Soluble whey protein aggregates and lipoproteins; 2 = Ig, BSA, lactoferrin, and lactoperoxidase; $3=$ $\beta$-LG; $4=\alpha$-LA; and $5=$ caseinomacropeptide.

the high and moderate gel strength products including WPC-A but was present at a level of about $11 \%$ in the low gel strength WPC $(\mathrm{G}, \mathrm{H}$, and I). This result was consistent with the presence of the $24-\mathrm{kDa}$ band on SDS-PAGE and indicated that these WPCs were derived from cheese or rennet whey.

The native molecular weight profile of the protein in the WPC was analyzed by gel filtration in phosphate buffer ( $\mathrm{pH}$ 7.0) to assess their aggregation state. Aggregated proteins eluted in the void, and, although the size of the void peak varied with each WPC, there was no clear association with gel strength or water-holding capacity. Two-dimensional gel electrophoresis of the 10 WPC samples (data not shown) revealed multiple isoelectric forms of the major whey proteins consistent with heat modification. This was confirmed by MALDIMS analysis, which showed lactosylation of $\alpha$-LA and 

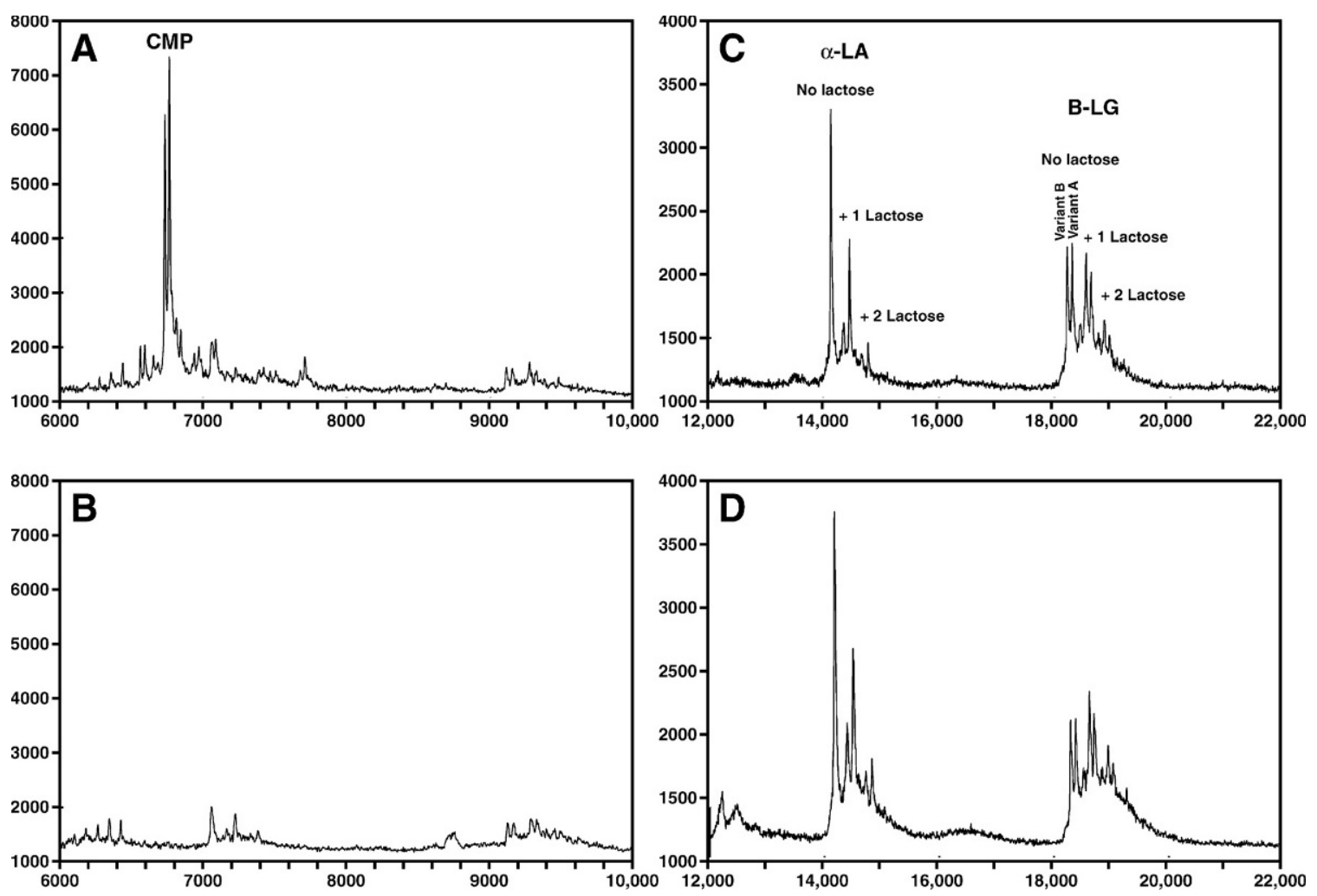

Figure 4. Matrix-assisted laser desorption ionization mass spectroscopy of whey protein concentrate (WPC)-G and -A. At $10 \mathrm{mg} / \mathrm{mL}$ of water, the WPC was diluted into $0.1 \%$ trifluoroacetic acid, $30 \%$ acetonitrile, and $70 \% \mathrm{H}_{2} \mathrm{O}$ and mixed $1: 1$ with saturated matrix in the same solvent. The matrix employed was 3,5 dimethoxy-4 hydroxy cinnamic acid. One microliter of sample was spotted onto the plate and analyzed in positive-ion mode. The WPC-G spectrum is presented in the mass region of caseinomacropeptide (CMP) from 6000 to $10,000 \mathrm{~m} / \mathrm{z}$ (A) and in the region of $\alpha$-LA and $\beta$-LG from 12,000 to 22,000 (C). The WPC-A spectrum is displayed over the same respective mass ranges in B and $\mathrm{D}$, respectively.

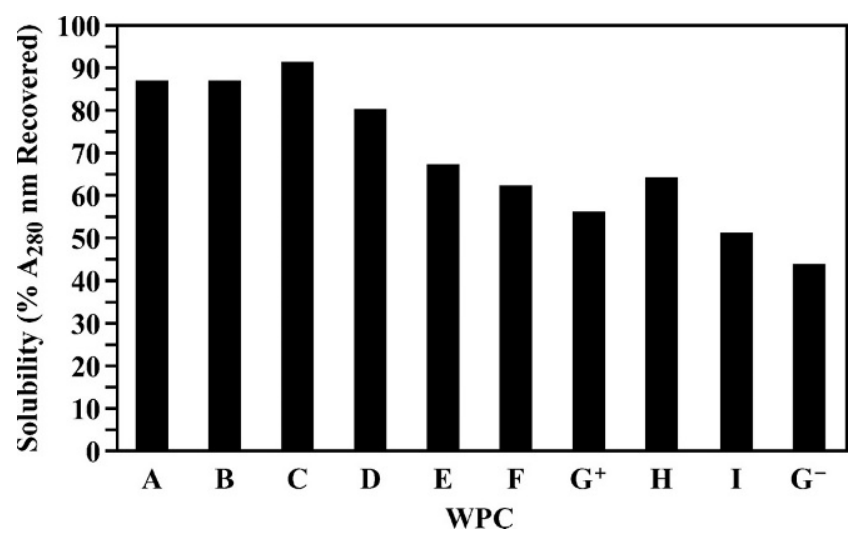

Figure 5. Solubility of whey protein concentrate (WPC). The WPC solutions at $0.50 \mathrm{mg} / \mathrm{mL}$ were adjusted to $\mathrm{pH} 7.0$. The absorbance at $280 \mathrm{~nm}$ was measured and re-measured after removal of insolubles by centrifugation at $11,600 \times g$. The percentage absorbance $(280$ $\mathrm{nm}$ ) recovered was used as an indicator of solubility. Data presented represent the mean of at least 3 separate determinations with the coefficient of variation $<10 \%$.

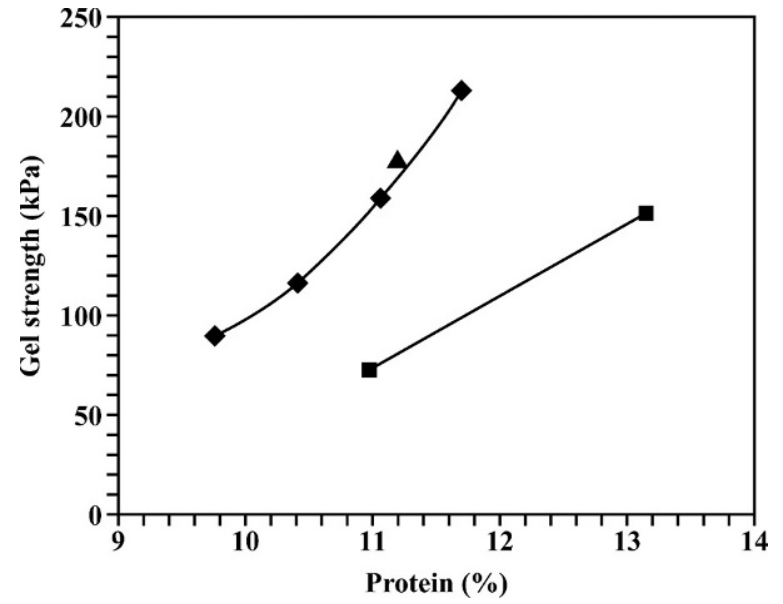

Figure 6. The whey protein concentrate (WPC)-G was reconstituted at $15,16,17$, and $18 \% \mathrm{wt} / \mathrm{wt}$ containing 11.0 to 13.2 total protein and 9.8 to $11.7 \%$ soluble protein as estimated by the Bradford protein assay (BioRad). The solutions were gelled without removal of insolubles ( $)$ and with removal of insolubles $(\bullet)$. The WPC-A at $15 \%$ WPC (11.2\% soluble protein) was also gelled with insolubles removed for comparison $(\mathbf{\Delta})$. 


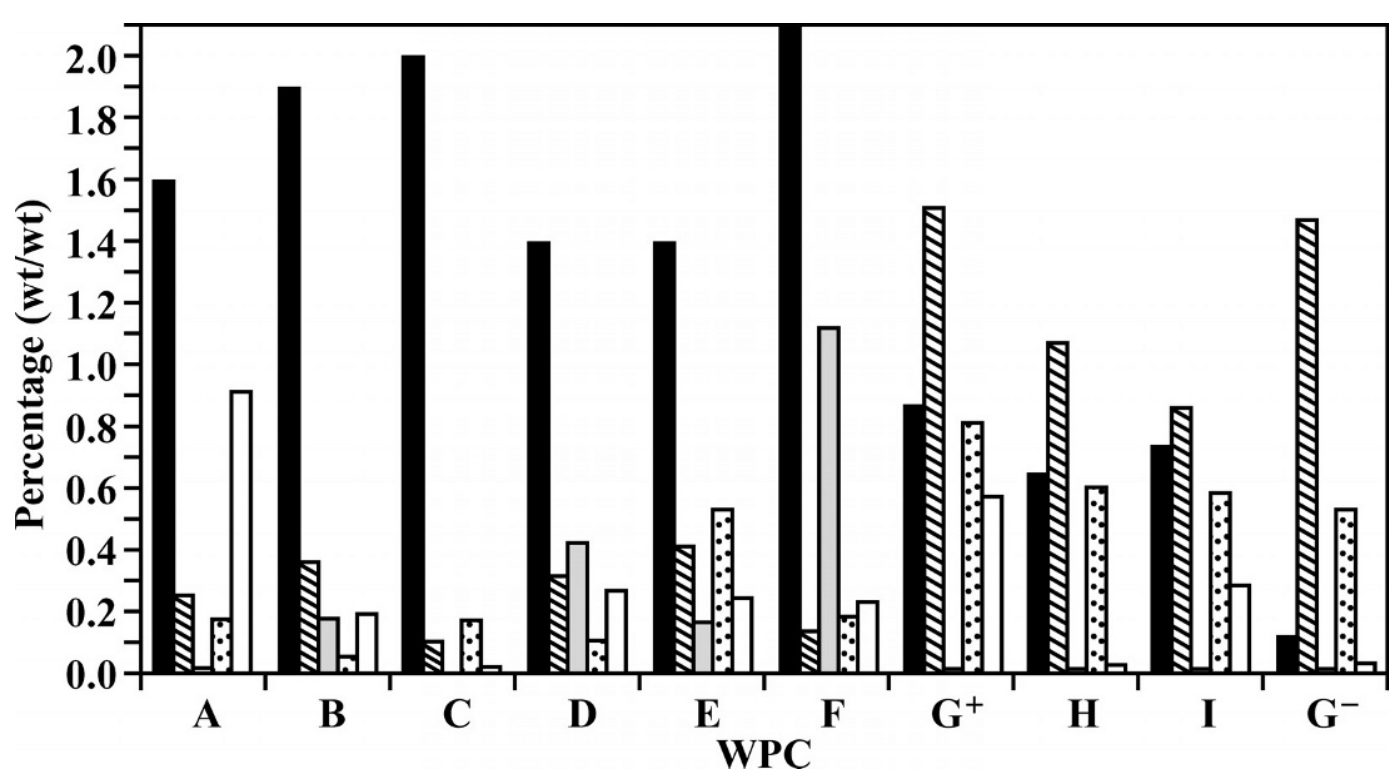

Figure 7. Ion analyses of whey protein concentrate (WPC). Levels of $\mathrm{Na}$ (solid), K (striped), and Ca (dotted) were determined by atomic absorption spectroscopy; phosphate level (open) was determined by colorimetric assay. Chlorine determinations (shaded) were performed by Dairy Technical Services (Melbourne, Australia). Results are expressed as the percentage (wt/wt) of the dry WPC powder and represent the mean of at least 3 separate determinations with the coefficient of variation $<10 \%$.

$\beta$-LG (Figure 4). However, the level of lactosylation was similar for both the high and low gel strength WPC and also appeared unrelated to water-holding capacity. Although protein content or modification could not be associated with gel strength or waterholding capacity, the content of soluble protein at $\mathrm{pH}$ 7 of the WPC was found to be closely associated with gel strength (Figure 5).

Because protein solubility was closely associated with gel strength, the relationship between solubility and gel strength was further investigated. Removal of insoluble material from WPC-G $\mathrm{G}^{+}$by centrifugation to produce solutions containing 9.8 to $11.7 \% \mathrm{wt} / \mathrm{vol} \mathrm{pro}-$ tein substantially improved gel strength (Figure 6). The corresponding gels, without removal of insoluble material, produced lower strength gels (Figure 6) even though they contained a higher total protein concentration, indicating that the presence of insoluble protein aggregates directly interfered with the formation of strong gels.

The ionic environment of the $10 \mathrm{WPC}$ was analyzed with respect to $\mathrm{pH}$, the cations $(\mathrm{Na}, \mathrm{K}, \mathrm{Ca}$, and $\mathrm{Mg}$ ) and the anions (C1 and phosphates) (Figure 7). The $\mathrm{pH}$ of fresh WPC solutions at $1 \% \mathrm{wt} / \mathrm{vol}$ varied from 6.4 to 7.2 with no association with gel strength or water retention. The type and amount of salt, however, was associated with gel strength and, with the exception of WPC-B, was also associated with water-holding capacity (Figure 7). The higher gel strength WPC tended to contain a low amount of all salts except
$\mathrm{Na}$ and $\mathrm{Cl}$, whereas the lower gel strength WPC all exhibited whey-like salt compositions with moderate levels of $\mathrm{Ca}, \mathrm{K}, \mathrm{Mg}$, and phosphate; low $\mathrm{Na}$; and almost no $\mathrm{Cl}$. These results suggest that the high to moderate gel strength products had been extensively processed to remove $\mathrm{Ca}, \mathrm{Mg}$, and $\mathrm{K}$ ions and that $\mathrm{Na}$ and $\mathrm{Cl}$ ions had been added. The WPC-A sample was found to contain a large amount of acid hydrolyzable phosphate that, by comparison with $\mathrm{G}^{+}$, would represent a 4 to $6 \% \mathrm{wt} / \mathrm{wt}$ sodium polyphosphate addition. The results, indicating that some WPCs contained higher levels of chloride, suggested that $\mathrm{HCl}$ had been used for acid processing such as for the production of acid $(\mathrm{HCl})$ whey and for $\mathrm{DF}$ at low $\mathrm{pH}$.

Because ionic environment of the WPC was clearly important for gel strength and water-holding capacity, this was investigated further by monitoring both gel strength and compressibility as well as water-holding capacity of a cold-processed WPC-G product after known additions of sodium polyphosphate or sodium chloride (Figure 8). The addition of polyphosphate clearly increased gel strength but, in general, had a deleterious effect on water-holding capacity (Figure $8 \mathrm{~A})$. However, the first addition of polyphosphate (2\%) substantially improved water-holding capacity. Gel stiffness increased to a maximum at about 4 to $6 \%$ sodium polyphosphate after which it became more compressible with further addition. To distinguish between the effects of sodium polyphosphate and sodium chloride, the experiment was repeated at a level of $2 \%$ 

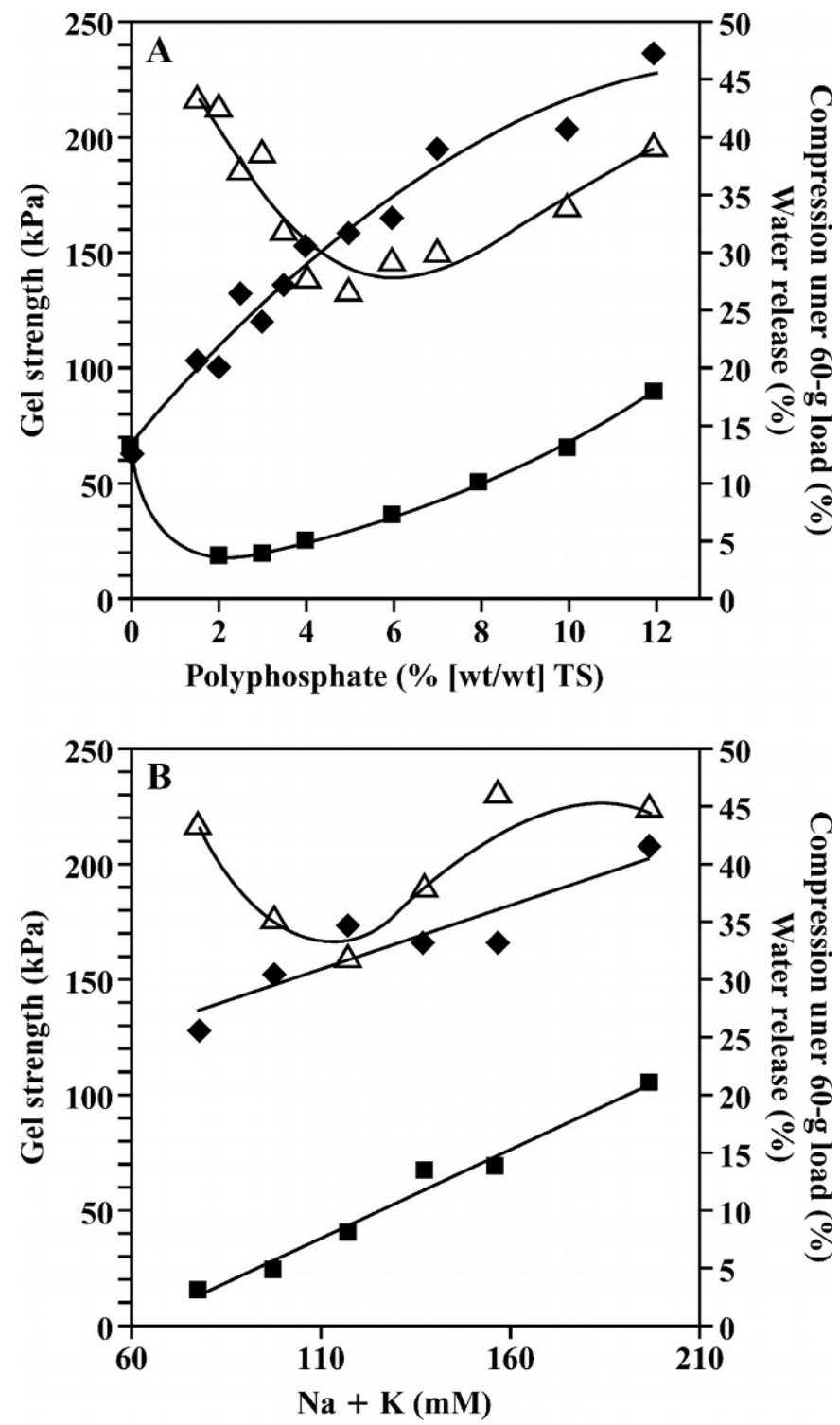

Figure 8. A) A cold-processed whey protein concentrate (WPC)$\mathrm{G}$ was reconstituted at $15 \%$ (wt/wt) with sodium polyphosphate added at increasing levels from 0 to $12 \%$ (wt/wt) relative to the WPC. B) Conditions similar to A with the exception that 15\% WPC-G with $2 \%$ polyphosphate was used throughout, and $\mathrm{NaCl}$ was added in increasing amounts to be equivalent to the concentration of sodium ions present when polyphosphate was added. Gel strength $(\bullet)$ and water release ( $\square$ ) were measured, and, in addition, the stiffness of the gel $(\triangle)$ was expressed as the percentage deformation (compression) of the gel under a load of $60 \mathrm{~g}$ of force.

polyphosphate, with increasing $\mathrm{NaCl}$ concentrations (Figure 8B) equivalent to the sodium polyphosphate addition (Figure 8A). These results indicated that the increase in ionic strength by the addition of either sodium polyphosphate or sodium chloride resulted in a decrease in water-holding capacity and ultimately gel stiffness. However, the polyphosphate anion rela-
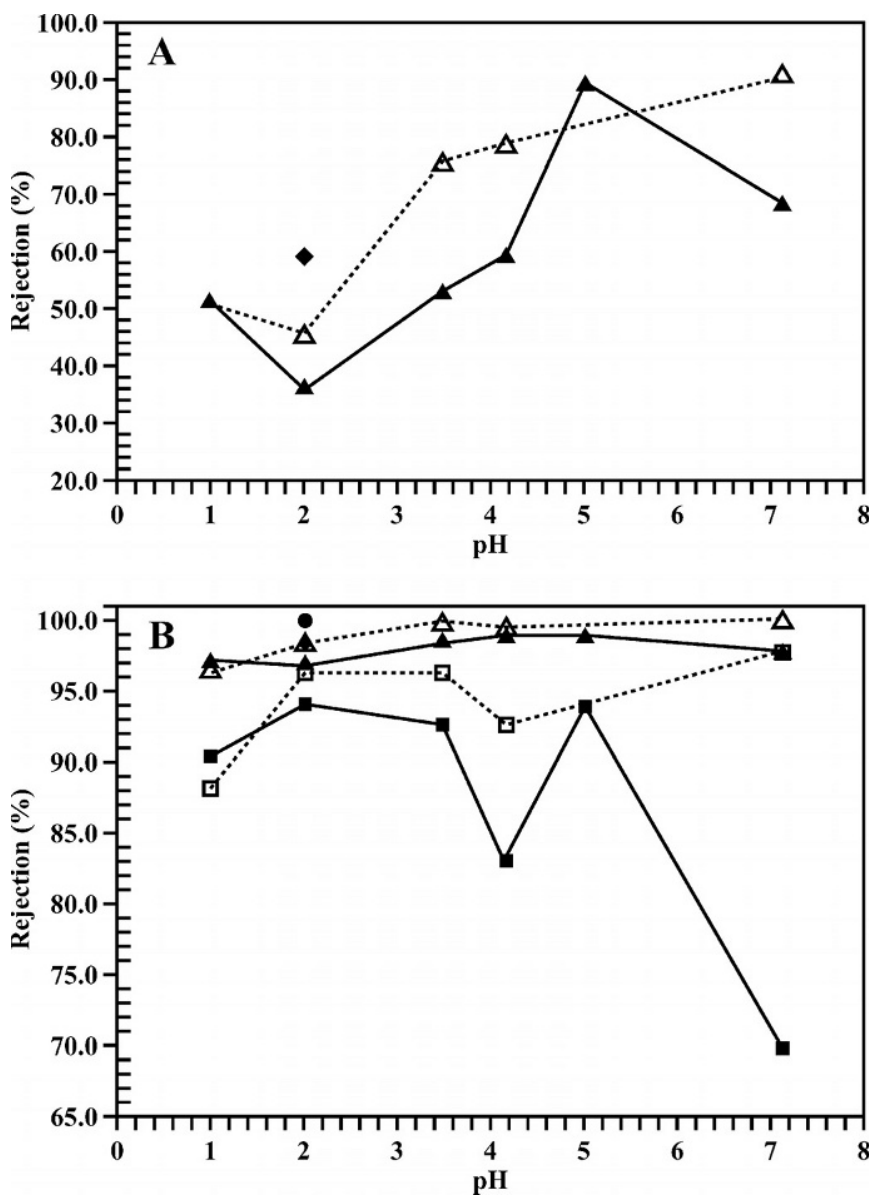

Figure 9. Effect of $\mathrm{pH}$ and UF membrane porosity on the rejection of caseinomacropeptide (CMP) (A) and $\beta$-LG and $\alpha$-LA (B). The whey protein concentrate (WPC)-G at $5 \mathrm{mg} / \mathrm{mL}$, adjusted to the $\mathrm{pH}$ indicated, was ultrafiltered through membranes with nominal molecular weight cut-off values ranging from 30 to $100 \mathrm{kDa}$. The filtrates were analyzed by HPLC gel filtration and compared with untreated WPC$\mathrm{G}$ to quantitate the rejection of protein. Rejection is expressed as the proportion of individual protein that did not pass through the membrane. A) CMP, $100 \mathrm{kDa}(\mathbf{\Delta})$; $\mathrm{CMP}, 50 \mathrm{kDa}(\triangle)$; CMP, $30 \mathrm{kDa}$ $(\diamond)$. B) $\beta$-LG, $100 \mathrm{kDa}(\mathbf{\Delta}) ; \beta$-LG, $50 \mathrm{kDa}(\triangle) ; \beta$-LG, $30 \mathrm{kDa}(\bullet) ; \alpha$ $\mathrm{LA}, 100 \mathrm{kDa}(\square) ; \alpha$-LA, $50 \mathrm{kDa}(\square) ; \alpha$-LA, $30 \mathrm{kDa}(\diamond)$.

tive to chloride had a more favorable effect on water retention, gel strength, and stiffness.

Gel filtration HPLC and SDS-PAGE analyses of the WPC samples revealed that the lowest gel strength WPC products ( $\mathrm{G}, \mathrm{H}$, and I) all contained CMP (Figures 2 and 3). Analysis of the samples by MALDI-MS (Figure 4) confirmed the presence of CMP in WPC-G, -H, and -I, indicating that the source of these products was rennet or cheese whey. Because gels produced using these WPC exhibited the lowest gel strength and water-holding capacity, the effect of CMP addition to the highest gel strength WPC, WPC-A, was investigated. Desalted, purified CMP was added to WPC-A at a level equal to that found in the cheese whey WPC, 


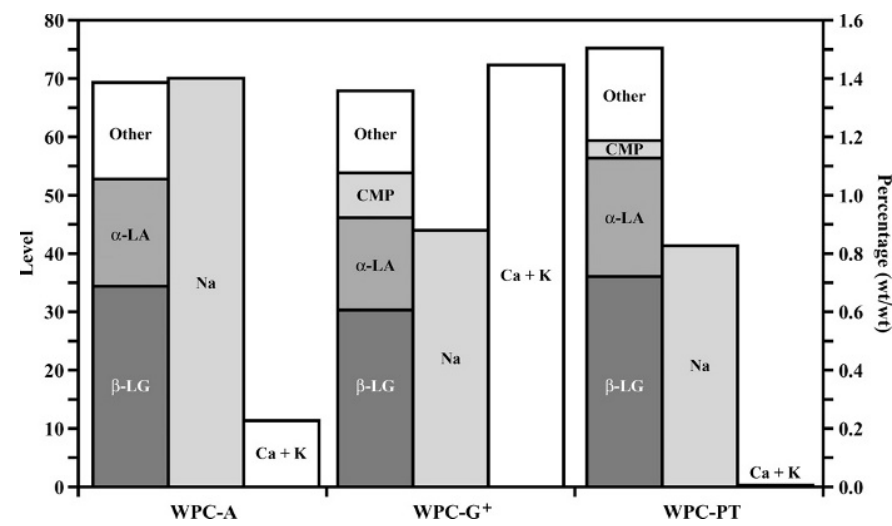

Figure 10. Protein composition and ion analyses of whey protein concentrate (WPC)-A, WPC-G ${ }^{+}$, and the process trial WPC-PT. Protein composition is absolute based on integrated gel filtration peak areas. CMP = Caseinomacropeptide.

WPC-G. The strength of the gel produced using WPCA + CMP was reduced, and the water loss from the gel was doubled.

Because the presence of the CMP in the WPC was clearly detrimental to gel strength and water-holding capacity, we investigated the selective removal of CMP

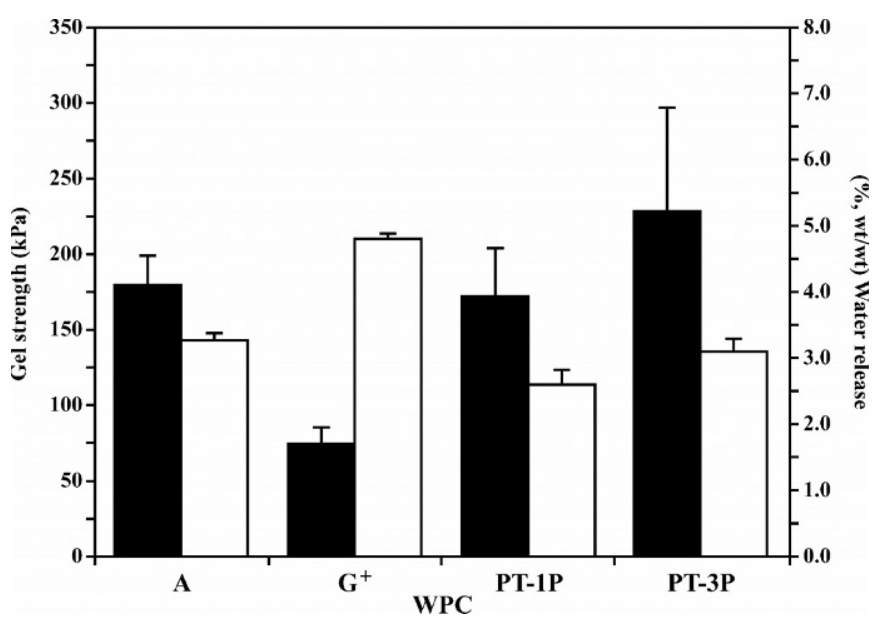

Figure 11. Gel strength $(\square)$ and water release $(\square)$ of whey protein concentrate (WPC)-A, WPC-G, and the process trial WPC-PT with the addition of $1 \%$ polyphosphate (PT-1P) and $3 \%$ polyphosphate (PT$3 \mathrm{P})$. WPC was reconstituted to $15 \%$, wt/vol, $\mathrm{pH} 7.0$ and cooked at $75^{\circ} \mathrm{C}$ for $70 \mathrm{~min}$. Cooled gel cylinders were tested for gel strength by recording the force-deformation curve produced when a rod of $3 \mathrm{~mm}$ diameter was pushed through the sample until failure. The gel strength was taken as the force at failure divided by the cross-sectional area of the rod. The gel strength presented is the mean measurement from at least seven gel cylinders. Water release was measured by compressing the gel between absorbent paper. The percentage water release was calculated as the weight of lost water divided by the initial gel weight and is presented as the mean of at least three measurements. Error bars represent one standard deviation from the mean. from cheese whey at various values of $\mathrm{pH}$ by UF at $15^{\circ} \mathrm{C}$ using membranes of different nominal MWCO values (Figure 9). The separation of CMP from the bulk of the whey proteins was assessed by analysis of the retentates and permeates from the UF experiments for $\beta$-LG, $\alpha$-LA, and CMP using quantitative gel filtration HPLC. The results are expressed in terms of protein rejection by the membrane (Figure 9). The rejection of CMP by the membrane decreased, with decreasing $\mathrm{pH}$ of the sample reaching a minimum at $\mathrm{pH} 2$, where the rejection was 36,46 , and $59 \%$ through $100-, 50-$, and $30-\mathrm{kDa}$ MWCO membranes, respectively (Figure 9A). In contrast, the rejection of $\beta$-LG and $\alpha$-LA was high at all $\mathrm{pH}$ values tested. Using the $50-\mathrm{kDa}$ MWCO membrane, 98 and $100 \%$ of $\alpha$-LA and $\beta$-LG, respectively, were rejected at $\mathrm{pH} 7$, and 96 and $99 \%$ were rejected, respectively, at $\mathrm{pH} 2$ (Figure 9B). These results indicated that $\mathrm{DF}$ of cheese whey at $\mathrm{pH}$ 2.5 through a $30-\mathrm{kDa}$ nominal MWCO membrane at $15^{\circ} \mathrm{C}$ should substantially reduce the content of CMP without significant losses of the major whey proteins.

\section{Process Trial}

Pasteurized, separated cheese whey was adjusted to $\mathrm{pH} 2.5$ with $\mathrm{HCl}$ and then concentrated 15 -fold by UF at $15^{\circ} \mathrm{C}$ through a $30,000 \mathrm{MWCO}$ membrane to $16 \%$ TS and then diafiltered through the same 30,000 MWCO membrane with 5 vol of deionized water. The $\mathrm{pH}$ was then adjusted to 7.4 with $\mathrm{NaOH}$, and $\mathrm{DF}$ was continued with 0.7 vol of deionized water. After DF, the TS were concentrated by further UF to $20 \% \mathrm{wt} / \mathrm{vol}$, and the product was freeze-dried. Gel filtration was used to monitor the proportion of $\beta$-LG, $\alpha$-LA, and CMP in the permeate and retentate during the trial. Caseinomacropeptide began at $15 \% \mathrm{wt} / \mathrm{wt}$ of protein in the cheese whey and fell to $5 \%$ in the retentate after DF.

The dried product WPC-PT contained 3.5\% wt/wt CMP, about one-third of the amount found in normal cheese whey, WPC-G. The Ca level was $<0.01 \%$, and the sodium was $0.83 \%$ before polyphosphate addition (Figure 10). The protein content was higher than all other products tested and was 9\% higher than WPCA (Figure 10). This increase in protein content is attributable to the high level of DF and, therefore, greater reductions in non-protein components such as mineral and lactose. The water retention of WPC-PT was superior to WPC-A even with the addition of $3 \%$ polyphosphate, where the release of water was $3.1 \%$ (Figure 11 ). The release was only $2.6 \%$ with $1 \%$ polyphosphate. Gel strength of WPC-PT with $1 \%$ polyphosphate was equivalent to WPC-A at $173 \pm 31 \mathrm{kPa}$ and was superior to WPC-A with $3 \%$ polyphosphate (Figure 11). 


\section{DISCUSSION}

The objective of this investigation was to develop an industrially relevant process for the production of a high gel strength and water-holding WPC from cheese whey. Our approach was to analyze 10 commercially available WPC that varied in functional properties to determine the specific composition associated with high gel strength and water-holding capacity. Because gel strength of a WPC has been associated with $\mathrm{pH}$, ionic environment, and protein concentration and composition, these were determined for all of the WPC samples and were related to their gel strength and water-holding capacities (Mulvihill and Kinsella, 1987; Mangino, 1992; Aguilera, 1995; Rojas, et al., 1997). The gel strength and water-holding capacities of gels produced using the WPC were tested using specific conditions relevant to the food industry. Food processors requiring high gel strength and water-holding WPC have specified conditions of neutral $\mathrm{pH}$, a cooking time of $70 \mathrm{~min}$, and a temperature of $75^{\circ} \mathrm{C}$ for certain applications; hence, these conditions were used for gel formation in this study.

The analysis of the 10 WPC revealed factors that were clearly associated with high gel strength and water-holding capacities, and these were the solubility and composition of the protein and the ionic environment.

A clear positive relationship between the content of soluble protein and gel strength was observed for the 10 commercial WPC analyzed. It was further noted that the presence of insoluble protein aggregates interfered with the formation of strong gels. The importance of protein concentration on gelation is well established (Mulvihill and Kinsella, 1987). Ferry (1948) first suggested that the process of gelation involved two stages. The first involved an initial denaturation or unfolding of a protein followed by subsequent aggregation. This was later modified by Schmidt (1981) and Aguilero (1995) to involve the following transitions: Step I, native protein $\rightarrow$ denatured protein; Step II, denatured protein $\rightarrow$ soluble aggregate; Step III, soluble aggregate $\rightarrow$ insoluble aggregate $(\rightarrow$ precipitate); Step IV, insoluble aggregate $\rightarrow$ gel.

A minimum protein concentration is required to form the concentration of soluble aggregates necessary to cross-link and form a gel network. The cross-linking of the soluble aggregates forms a homogeneous network of interconnected, highly solvated protein molecules in a 3-D matrix with interstices filled by aqueous solution. If denaturation occurs at a protein concentration below the minimum required for gel formation, the soluble aggregates can form insoluble particles that precipitate out of solution. The results of the present study show that the formation of precipitated protein aggregates is detrimental to the formation of strong gels. The presence of the insoluble aggregates in the commercial WPC is likely to be attributable to exposure of the whey to high temperatures either during pretreatment or processing. Hence, to maintain protein solubility, it is essential to minimize exposure of the whey to extended periods of high temperature.

The other major factor affecting gel strength identified in this study was protein composition. $\beta$-Lactoglobulin is the most abundant whey protein, comprising up to $50 \% \mathrm{wt} / \mathrm{wt}$ of the total whey protein, and is the most important protein for gelation (Mulvihill and Kinsella, 1987). In the current study, we have shown that the presence of CMP in the WPC is detrimental to gel strength and water-holding properties. Caseinomacropeptide is released from $\kappa$-CN by action of chymosin and is, therefore, present in cheese or rennet whey, but not in acid whey. Caseinomacropeptide is a glycosylated and phosphorylated peptide with quite different properties in comparison with the globular proteins, such as $\beta$-LG, involved in gel formation. The detrimental effect of CMP on gel strength and waterholding capacity demonstrated in this study would be consistent with CMP not incorporating into the protein gel network and competing for water binding. Although the molecular weight of CMP is $<10,000$, at neutral $\mathrm{pH}$, its apparent molecular weight is $30 \mathrm{kDa}$ because of its large hydrodynamic volume as measured by gel filtration chromatography (Kawasaki et al., 1993). However, the hydrodynamic volume of the peptide collapses at low $\mathrm{pH}$ upon protonation of acidic groups (Kawasaki et al., 1993). We have shown in this study that UF and DF of cheese whey at $\mathrm{pH} 2.5$ through a 30,000 nominal MWCO membrane at $15^{\circ} \mathrm{C}$ substantially reduced the content of CMP in the resulting WPC without affecting the integrity of the other whey proteins.

Ionic environment also was an important factor in determining gel strength and water-holding capacity of the WPC. All commercial WPC that produced high strength gels exhibited ionic compositions that were consistent with acidic $(\mathrm{HCl})$ processing to remove cations, in particular $\mathrm{Ca}$ ions, with subsequent neutralization with sodium hydroxide. The gel that exhibited the highest strength and water-holding capacity was produced from WPC-A, which, from analysis, appeared to contain 4 to $6 \% \mathrm{wt} / \mathrm{wt}$ sodium polyphosphate. The addition of sodium polyphosphate, in this study, to a WPC significantly increased gel strength and, up to $2 \%$ sodium polyphosphate, also significantly increased water-holding capacity. Nakai and Li-Chen (Nakai and Li-Chen, 1985) reported that treatment of WPC with polyphosphate improved gel strength through 
chelation of excess Ca ions. However, polyphosphate is also likely to facilitate protein cross-linking through binding to protein-surface positive charges. Polyphosphate incorporation into the protein gel network would be expected to increase water-holding capacity.

The acidic DF process developed to remove CMP from cheese whey also efficiently removed lactose and minerals. Thus, this process produced a low ionic strength WPC amenable to sodium polyphosphate addition. The trial described produced a WPC that, with the addition of $3 \% \mathrm{wt} / \mathrm{wt}$ sodium polyphosphate, produced a gel of strength $230 \mathrm{kPa}$ that lost only $3.1 \%$ of its water upon compression.

In conclusion, we have developed a pilot-scale UFDF procedure for processing cheese whey under acidic conditions that produced a high gel strength and water-holding capacity WPC.

\section{REFERENCES}

Adamson, N. J., and E. C. Reynolds. 1995. Characterization of tryptic casein phosphopeptides prepared under industrially relevant conditions. Biotechnol. Bioeng. 45:196-204.

Aguilera, J. M. 1995. Gelation of whey proteins. Food Technol. 49:83-89.

Ferry, J. D. 1948. Protein gels. Adv. Protein Chem. 4:1-76.
Kawasaki, Y., H. Kawakami, M. Tanimoto, S. Dosako, A. Tomizawa, M. Kotake, and I. Nakajima. 1993. Ph-dependent molecularweight changes of $\kappa$-casein glycomacropeptide and its preparation by ultrafiltration. Milchwiss.-Milk Sci. Int. 48:191-196.

Laemmli, U. K. 1970. Cleavage of structural proteins during the assembly of the head of bacteriophage T4. Nature 227:680-685.

Mangino, M. E. 1984. Physicochemical aspects of whey protein functionality. J. Dairy Sci. 67:2711-2722.

Mangino, M. E. 1992. Gelation of whey-protein concentrates. Food Technol. 46:114-117.

Mei, F. I., I. Laye, D. Karleskind, and C. V. Morr. 1996. Gelation of calcium-reduced and lipid-reduced whey protein concentrates as affected by total and ionic mineral concentrations. J. Food Sci. 61:899-905.

Morr, C. V. 1992. Improving the texture and functionality of wheyprotein concentrate. Food Technol. 46:110-113.

Morr, C. V., and E. A. Foegeding. 1990. Composition and functionality of commercial whey and milk protein-concentrates and isolatesA status-report. Food Technol. 44:100-112.

Mulvihill, D. M., and J. E. Kinsella. 1987. Gelation characteristics of whey proteins and $\beta$-lactoglobulin. Food Technol. 41:102-111.

Nakai, S., and E. Li-Chen. 1985. Structure modification and functionality of whey proteins: quantitative structure-activity relationship approach. J. Dairy Sci. 68:2763-2772.

Rojas, S. A., H. D. Goff, V. Senaratne, D. G. Dalgleish, and A. Flores. 1997. Gelation of commercial fractions of $\beta$-lactoglobulin and $\alpha$ lactalbumin. Int. Dairy J. 7:79-85.

Schmidt, R. H. 1981. Gelation and coagulation in Protein Functionality in Foods. J. P. Cherry, ed. Am. Chem. Soc., Washington, DC.

Tang, Q. N., O. J. McCarthy, and P. A. Munro. 1994. Oscillatory rheological comparison of the gelling characteristics of egg-white, whey-protein concentrates, whey-protein isolate, and $\beta$-lactoglobulin. J. Agric. Food Chem. 42:2126-2130. 